\title{
Impairment on nuclear maturation rate in oocytes from cows naturally infected by bovine herpesvirus 1 (BoHV-1) ${ }^{1}$
}

\author{
Vívian R.A. Mendes ${ }^{2}$, Eduardo P. Costa², Vanessa L.D. Queiroz ${ }^{2 *}$, \\ Abelardo Silva Júnior ${ }^{2}$, Saullo V.P. Alves ${ }^{2}$, José D. Guimarães ${ }^{2}$ and Lidiany L. Gomes ${ }^{2}$
}

ABSTRACT.- Mendes V.R.A., Costa E.P., Queiroz V.L.D., Silva Júnior A., Alves S.V.P., Guimarães J.D. \& Gomes L.L. 2018. Impairment on nuclear maturation rate in oocytes from cows naturally infected by bovine herpesvirus 1 (BoHV-1). Pesquisa Veterinária Brasileira 38(12):2207-2212. Universidade Federal de Viçosa, Avenida PH Rolfs s/n, Campus Universitário, Centro, Viçosa, MG 365700-000, Brazil. E-mail: vanessalopq@gmail.com

Bovine herpesvirus 1 (BoHV-1) is an important bovine pathogen that is responsible for causing respiratory diseases and reproductive failures. The presence of BoHV-1 in an in vitro embryo production system affects fertilization, maturation, and embryonic development. The objective of this study was to evaluate the developmental capacity of oocytes from naturally infected cows with no reproductive history. Moreover, this study investigated the presence of viral DNA in cumulus oophorus complexes (COCs). Experimental groups were differentiated by titrating the antibodies detected through seroneutralization assays, establishing three groups: seronegative animals (titer lower than 2), low titer (2 to 8), and animals with a titer above or equal to 16. COCs were obtained from 15 donors during 22 sessions of ultrasound-guided follicular aspiration. DNA was extracted from a pool of COCs obtained from all aspirations from the same donor as well as from whole blood and nested PCR reactions were performed. Only COCs with a compact layer of cumulus cells, an intact zona pellucida, and homogeneous cytoplasm were selected for in vitro culture and evaluation of nuclear maturation rate. After culturing for 24 hours, the oocytes were fixed and stained to evaluate the meiotic cell cycle stage. Oocytes that showed a chromosomal configuration in metaphase II were considered to have reached nuclear maturation. Compared with the other groups, the oocyte nuclear maturation rate in animals with a titer greater than or equal to $16(50 \%)$ was compromised $(P<0.05)$. However, the viral titer did not influence the maturation rate of bovine oocytes in animals exhibiting low titration (62.2\%) when compared with the control group (76.7\%). Viral DNA was not observed in the blood samples but was detected in the COC pool from three seropositive donors. In view of the results obtained, we conclude that natural infections by the BoHV-1 virus can compromise the nuclear maturation rate in cows, depending on the titration levels of antibodies against the virus. Moreover, viral DNA could be present in COCs, contradicting the hypothesis that seropositive animals with no history of clinical symptomatology pose a negligible risk of transmitting BoHV-1 by COCs.

INDEX TERMS: Nuclear maturation rate, oocytes, bovine herpesvirus 1, BoHV-1, IBR, maturation, cattle, pathology.

RESUMO.- [Comprometimento na taxa de maturação nuclear em ovócitos de vacas naturalmente infectadas pelo herpesvírus bovino 1 (BoHV-1).] Herpesvírus bovino

\footnotetext{
${ }^{1}$ Received on June 4, 2018.

Accepted for publication on July 16, 2018.

${ }^{2}$ Programa de Pós-Graduação em Medicina Veterinária, Departamento de Veterinária, Universidade Federal de Viçosa (UFV), Avenida P.H. Rolfs s/n, Campus Universitário, Viçosa, MG 36570-000, Brazil. *Corresponding author: vanessalopq@gmail.com
}

1 (BoHV-1) é um importante patógeno bovino, responsável por causar doenças respiratórias e falhas reprodutivas. A presença do BoHV-1 em sistema de produção in vitro de embriões afeta a fertilização, a maturação e o desenvolvimento embrionário. 0 objetivo deste estudo foi avaliar a capacidade de desenvolvimento de ovócitos oriundos de vacas infectadas naturalmente sem histórico reprodutivo. Além disso, este estudo investigou a presença do DNA viral em Complexos Cumulus Ooforus (COCs). Os tratamentos foram definidos a partir do título 
de anticorpos detectados pelos ensaios de soroneutralização, sendo estabelecidos três grupos: animais soronegativos (título menor do que 2), título baixo (2 a 8) e animais com título maior ou igual a 16. Os COCs foram obtidos de 15 doadoras durante 22 sessões de aspiração folicular guiada por ultrassom. A extração do DNA foi realizada em um pool de COCs de todas as aspirações de uma mesma doadora e no sangue total para a realização das reações de Nested-PCR. Para avaliação da taxa de maturação nuclear, foram selecionados para o cultivo in vitro somente os COCs com camada compacta de células do cumulus, zona pelúcida íntegra e citoplasma homogêneo. Após 24 horas de cultivo, os ovócitos foram fixados e corados em lâmina para a avaliação do estádio do ciclo celular meiótico. Os ovócitos que apresentaram configuração cromossômica em metáfase II foram considerados como tendo alcançado a maturação nuclear. Verificou-se comprometimento na taxa de maturação nuclear ovocitária $(\mathrm{P}<0.05)$ nos animais de título maior ou igual a 16 (50\%). No entanto, não houve influência do título viral na taxa de maturação de ovócitos bovinos em animais que apresentaram titulação baixa $(62,2 \%)$ quando comparados com o grupo controle $(76,7 \%)$. 0 DNA viral não foi identificado nas amostras de sangue, mas foi detectado no pool de COCs de três doadoras soropositivas. Diante dos resultados encontrados conclui-se que vacas infectadas naturalmente pelo vírus BoHV-1 apresentam comprometimento na taxa de maturação nuclear, dependendo do grau de titulação de anticorpos contra o vírus. Ademais, o DNA viral pode estar presente em COCs contrariando a hipótese de que animais sorologicamente positivos e sem histórico de sintomatologia clínica oferecem risco negligível de transmissão do BoHV-1 por COCs.

TERMOS DE INDEXAÇÃO: Taxa de maturação nuclear, ovócitos, vacas, herpesvírus bovino 1, BoHV-1, IBR, maturação, bovinos, patologia.

\section{INTRODUCTION}

Bovine herpesvirus 1 (BoHV-1) is the causative agent of infectious bovine rhinotracheitis (IBR). It is widespread in herds around the world (Ackermann \& Engels 2006, Nandi et al. 2011, Ravishankar et al. 2013).

The infection has several clinical forms that can compromise the respiratory system and genitals of infected animals. In the context of reproduction, BoHV-1 could cause repetition of estrus at regular or irregular intervals, embryonic death or abortions (Miller \& Van der Maaten 1986). The economic losses associated with the lost productivity and reproductive problems caused by the infection are extensive. An average financial expense of US $\$ 379.00$ per cow is estimated (Can et al. 2016).

Brazil currently has the largest commercial cattle herd in the world, with 218.2 million animals in 2016 (IBGE 2017). National data obtained from serological surveys revealed a prevalence of BoHV-1 of $42.2 \%$ in São Paulo (Mueller et al. 1981), 52.9\%, 71.3\%, and 81.7\% in Rio Grande do Sul (Ravazzolo et al. 1989, Vidor et al. 1995, Piovesan et al. 2013, respectively). In the state of Minas Gerais, studies conducted in 335 municipalities showed that $93.4 \%$ of the animals had positive serology for BoHV-1. In Paraná, 71.3\% of the 2,018 unvaccinated herds were positive for BoHV-1 (Rocha et al. 2001).

All Alphaherpesvirinae viruses can establish latent infections, making the animals lifelong carriers and potential disseminators of the virus. Latently infected animals, after primo-infection, usually carry the viral genome in the episomal form, especially in the trigeminal and sacral ganglia. Under conditions of stress or corticotherapy, BoHV-1 can be reactivated, leading to episodes of viral re-excretion, facilitating transmission while hindering control (Kramps et al. 1996, Jones et al. 2000, Winkler et al. 2000, El Mayet et al. 2017).

Vaccination is recommended in locations where herpesvirus infection is endemic (Patel 2005). It is noteworthy that in Brazil there is no program for the control and eradication of BoHV-1, nor is there any commercial availability of marked vaccines (distinguishing vaccinated animals from those naturally infected), strategies which have allowed countries such as Austria, Denmark, Finland, Switzerland, Sweden, and Norway to achieve a virus-free status (Can et al. 2016).

The use of reproductive biotechniques such as artificial insemination and embryo transfer have reduced pathogen transmission. However, the risks of these techniques in the transmission of pathogens should not be disregarded (Thibier \& Wrathall 2012). During the last few years, it has been shown that BoHV-1 can be present in the material used in the in vitro production system (Vanroose et al. 1999), associated with uterine tube epithelial cells and oocytes (Bielanski et al. 1993), in the follicular fluid (Weber et al. 2013), and in the spermatozoa of infected bulls (Rocha et al. 1998).

Furthermore, BoHV-1 can replicate in cumulus oophorus cells (COCs) and cause the cytopathic effect (cell lysis) characteristic of herpesviruses (Tsuboi et al. 1992, Tsuboi \& Imada 1997). Moreover, the viral DNA of BoHV-1 has been detected in COCs from seropositive cows with no history of vaccination or clinical symptomatology of the disease (Oliveira 2014).

In this context, this study investigated the effects of using COCs from naturally infected cows on the oocyte nuclear maturation rate. Moreover, the presence of viral DNA was also observed in COCs of these animals.

\section{MATERIALS AND METHODS}

Ethics statement. All of the experimental procedures were conducted following the ethical principles adopted by the National Council for Animal Experimentation, and with the authorization of the Committee of Ethics in Animal Use of the Federal University of Viçosa under protocol number 112/2011.

Animals and procedures. Fifteen adult Holstein x Gir crossbred bovine females of different blood grades, were used in different phases of the estrous cycle. These animals came from herds located in Zona da Mata (State of Minas Gerais, Brazil), and had not been vaccinated against BoHV-1 to avoid an interference of vaccination with the results. None of the cows presented clinical symptoms of IBR.

Blood samples were collected in tubes without anticoagulant for the seroneutralization technique and with anticoagulant for the nested PCR technique. Both were transported at room temperature and centrifuged for five minutes at $1500 \mathrm{G}$ for the separation of blood serum.

For the selection of the oocyte donor cows, blood samples were collected and serum neutralization was performed in microplates according to the methodology proposed by the "Manual of Standard for Diagnostic Tests and Vaccines" (OIE 2010). Then, the animals were divided into three groups according to the title of antibodies: five animals with low title (2 to 8), seven with title greater than or 
equal to 16 (Santos et al. 2014) and three serum-negative animals were used as controls.

Follicular aspiration by Ovum Pick-up (OPU). The follicular aspirations were conducted after the animals were properly restrained and intercoccygeal epidural anesthesia was used. For this procedure, an ultrasound device (DPS Mindray DP-2200VET) equipped with a micro convex transducer adjusted to an eight $\mathrm{MHz}$ frequency and coupled to an intravaginal guide was used. A vacuum pump (pressure of $80 \mathrm{mmHg}$, corresponding to $14 \mathrm{~mL}$ of water/min), and 40x10 (19G) needles were used. Follicles larger than two millimeters were punctured and the material collected was transported in $50 \mathrm{~mL}$ plastic tubes (Falcon) containing $5 \mathrm{~mL}$ of phosphate buffered saline (PBS) and $1000 \mathrm{IU}$ heparin at $37^{\circ} \mathrm{C}$. The aspirated contents were extensively washed with PBS solution to remove blood cells.

Experimental design. The COCs were screened under a stereoscopic microscope and transferred to another plate containing TALP-Hepes medium for maintenance. Subsequently, they were categorized following the methods of Costa et al. (1997a). The oocytes destined for in vitro maturation were packed in $0.25 \mathrm{~mL}$ straws in TALP-Hepes medium and packed in an embryo transporter at a controlled temperature of $38^{\circ} \mathrm{C}$. The other COCs were packed in microtubes and frozen at $-20^{\circ} \mathrm{C}$ for later detection of viral DNA by nested PCR.

Nested PCR was performed to detect the viral DNA of BoHV-1. Nested PCR for BoHV-5 was also performed, since cross-reactivity could occur through the seroneutralization.

In the laboratory, the straws containing the COCs were cut, and the contents were transferred to a culture dish on a hot plate at $38^{\circ} \mathrm{C}$ containing TALP-Hepes. The COCs were re-screened, washed in TALP-Hepes microdroplets and transferred to a culture dish with a pre-equilibrated TCM 199 medium supplemented with $10 \%$ serum of cow in estrus and $10 \mu \mathrm{g} / \mathrm{ml}$ of FSH (Costa 1994). The COCs were cultured for 24 hours in an incubator at $38.5^{\circ} \mathrm{C}$ in an atmosphere of 5\% CO2, 95\% atmospheric air and 95\% humidity. The nuclear maturation rate of the COCs was then evaluated.

The cultured COCs were transferred to a multiwell plate containing $300 \mu \mathrm{L}$ of TALP-Hepes medium for nuclear maturation rate evaluation. Then, the COCs were subjected to the cumulus oophorus removal procedure (Costa et al. 1997a), and were hypotonized, fixed on a slide, and stained with $2 \%$ orcein, following methods described by Costa et al. (1997b). The slides were read under an optical microscope with a magnification of $1000 \mathrm{X}$ in immersion. The oocytes that presented a chromosomal configuration in metaphase II were considered to have reached nuclear maturation.

Viral DNA was detected using nested PCR to check for the presence of BoHV-1. Total DNA was extracted from the COCs following the specifications of the manufacturer of the "SV Wizard Genomic" (Promega ${ }^{\circledR}$ ) extraction kit. The oligonucleotide sequence and protocol for the nested PCR reactions were standardized as described by Campos et al. (2009).

Statistics. The qualitative variables were compared in contingency tables and analyzed by the chi-square test with the significance level set at $5 \%$ probability (Sampaio 2002).

\section{RESULTS}

A total of 674 COCs were recovered from 15 donors during 22 OPU sessions. Approximately 400 COCs were evaluated by nested PCR, and 165 were evaluated to determine the nuclear maturation rate. The oocytes presenting a particular chromosomal configuration at metaphase II were considered as having undergone nucleus maturation. Regarding the nuclear maturation rate, however, the number of oocytes from each treatment was enough for an appropriate interpretation. The variable "maturation rate" is dichotomous, requiring analysis by the chi-square test.

The results obtained following in vitro culture of oocytes are shown in Table 1. Animals that had titers above or equal to 16 demonstrated a compromised oocyte nuclear maturation rate.

Seronegative animals did not contain viral DNA in the analyzed samples. However, a positive reaction was observed by nested PCR (Fig.1) in three animals (3/12), revealing the presence of BoHV-1 DNA in the COC pool. Out of these positive animals, two had low titers against BoHV-1 (2 of 3), and one animal had a titration greater than or equal to 16 (1 of 3).

\section{DISCUSSION}

The possible interference of infectious diseases in reproductive biotechnologies is a cause for concern, especially when gametes and embryos, potential disseminators of these diseases, are affected (Perry 2005).

Brazil assumes a prominent role in using biotechnology. In 2014, Brazil was considered the world's largest producer of bovine embryos, holding 366,517 embryos, which corresponds to about $70 \%$ of the world's total (IETS 2015).

Researchers using the polymerase chain reaction (PCR) test to detect BoHV-1 DNA have concluded that the risk of transmission of BoHV-1 by COCs and follicular fluid from seropositive cows without clinical symptomatology is irrelevant (Oliveira et al. 2016), since the presence of viral DNA was not observed in any of their tested samples.

In contrast, the presence of viral DNA was reported in $4.3 \%$ $(5 / 117)$ of the samples of ovarian tissue, $0.9 \%(1 / 115)$ of

Table 1. Nuclear maturation rate of animals with different antibody titers to BoHV-1

\begin{tabular}{lccc}
\hline \multirow{2}{*}{ Treatment } & $\begin{array}{c}\text { Evaluated } \\
\text { oocytes }\end{array}$ & \multicolumn{2}{c}{ Nuclear maturation } \\
\cline { 3 - 4 } & 30 & 23 & $\%$ \\
\hline Negative titer $(<2)$ & 45 & 28 & $76.7^{\mathrm{a}}$ \\
Low titer (2-8) & 90 & 45 & $62.2^{\mathrm{a}}$ \\
Titer $>16$ & 165 & 96 & $50.0^{\mathrm{b}}$ \\
TOTAL & & 58.2
\end{tabular}

a, b Percentiles with different superscribed letters indicate a significant difference $(\mathrm{P}<0.05)$ by chi-square analysis.

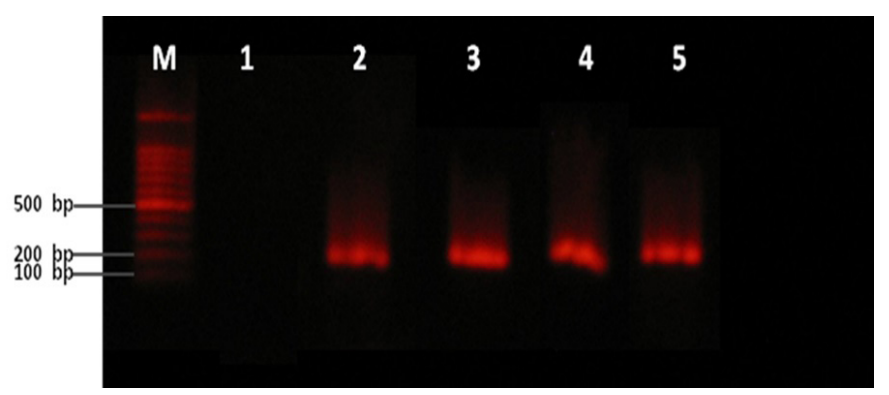

Fig.1. Visualization of PCR products on a $1 \%$ agarose gel, showing the detection of BoHV-1 DNA in COCs of seropositive cows $(\mathrm{M}=$ marker, $1=$ negative control, 2 = positive control, $3-5=$ positive COC samples). 
oocytes and in none of the follicular fluid samples of naturally infected seropositive cows without symptoms (Pereira et al. (2015). The same outcome was reported in this experiment from nested PCR results. The presence of BoHV-1 viral DNA was observed in pooled COCs from naturally infected seropositive animals without clinical symptoms of the disease.

Nested PCR is more sensitive than other techniques routinely used to detect BoHV-1, since it is based on two reactions derived from a DNA template. In addition, this technique is more suitable for molecular research on structures with a low viral load (Rocha et al. 1999, Moore et al. 2000, Olmos et al. 2003, Takiuchi et al. 2005).

The nested PCR method enabled the identification of the genomes of BoHV-1, BoHV-5, or both in 85.9\% (213/248) of the animals, whereas the seroneutralization method identified only $44.8 \%(111 / 248)$, and the ELISA method identified $51.2 \%$ (127/248) (Puentes et al. 2016). Puentes et al. (2016) emphasized that the detection of latently infected animals still depends on the postmortem identification of viral DNA in the trigeminal ganglion. Thus, the non-detection of viral DNA in the blood in this study can be explained by the brief period of acute disease manifestation in naturally infected animals or by the viral latency state in the sensorial and autonomic ganglia - a typical mechanism of the subfamily Alphaherpesvirinae (Spear 2004).

Oocyte infection by BoHV-1 has been reported to compromise embryonic development in in vitro and in vivo production (Bielanski et al. 1997, Makarevich et al. 2007). However, our results indicate that the deleterious effects of the virus on the oocyte also include compromised oocyte development, even before fertilization, by impacting the oocyte nuclear maturation rate. Moreover, this effect was dependent on the serological antibody titer.

Cumulus cells play a key role in the substrate supply, transport, and production of chemical components for the oocyte, such as microRNAs (regulators of genes involved in maturation processes) during oocyte maturation (Gilchrist et al. 2016). In addition, inhibitory and meiosis-inducing factors effect maturation through the communication of cumulus cells with the oocyte mediated by gap junctions (Mahmoudi et al. 2005).

The compromised oocyte nuclear maturation rate observed in this study may be explained by the interaction of BoHV-1 with cumulus cells. The virus has glycoproteins in its envelope that are responsible for adsorption and fusion with the plasma membrane of the host cell. Then, it enters the intracellular environment and begins a lytic replicative cycle incompatible with cellular survival (Muylkens et al. 2007). Although not investigated in this study, the death of cumulus cells infected by BoHV-1, due to the cytopathic effect of the virus, could contribute to the reduction of the number of viable cells capable of supporting oocyte competence.

Despite the negative interference in the oocyte nuclear maturation rate, no morphological differences were observed in optical microscopy in COCs before and after in vitro culture. This agrees with observations by D'Angelo (1998), who found that both bovine oocytes matured in vitro with BoHV-1 and those matured in the absence of the virus had indistinguishable morphology. This finding was also verified by Gonçalves et al. (2015), who also did not observe any morphological alterations in infected oocytes.
However, despite the normal morphological appearance, cellular damage that compromises later development occurs once BoHV-1 causes a cytopathic effect on cumulus cells without interfering with their expansion (Vanroose et al. 1999). It is worth mentioning that the condition of cumulus cells is one of the main aspects used in the evaluation of COCs (Costa 1994). Therefore, the analysis of COCs for embryo production in vitro is virtually always based only on observations of oocytes enveloped by layers of cumulus cells.

In summary, our findings provide relevant information at the COC level, since BoHV-1 compromises the rate of oocyte nuclear maturation through an interaction with cumulus cells without causing morphological changes visible under the optical microscope. Further research is needed to clarify the mechanism by which BoHV-1 interacts with the naturally infected bovine gamete.

\section{CONCLUSIONS}

Cows naturally infected by BoHV-1 exhibit compromised nuclear oocyte maturation, depending on the antibodies titration degree against the virus.

Furthermore, viral DNA may be present in COCs, contradicting the hypothesis that serologically positive animals with no history of clinical symptomatology pose a negligible risk of transmitting BoHV-1 by COCs.

Acknowledgements.- The authors are grateful to the Research Foundation of the State of Minas Gerais (FAPEMIG) and to the National Council of Scientific Development (CNPq) for the financial support of this study and Coordenation from the Improvement of Higher Level Personnel (CAPES).

Conflict of interest statement.- The authors declare no conflict of interest.

\section{REFERENCES}

Ackermann M. \& Engels M. 2006. Pro and contra-IBR eradication. Vet. Microbiol. 113(3/4):293-302. <http://dx.doi.org/10.1016/j.vetmic.2005.11.043> <PMid:16337098>

Bielanski A., Lutze-Wallace C., Sapp T. \& Jordan L. 1997. The efficacy of trypsin for disinfection of in vitro fertilized bovine embryos exposed to bovine herpesvirus 1. Anim. Reprod. Sci. 47(1/2):1-8. <http://dx.doi. org/10.1016/S0378-4320(97)00002-X><PMid:9233501>

Bielanski A., Loewen K.S., Del Campo M.R., Sirard M.A. \& Willadsen S. 1993. Isolation of bovine herpesvirus-1 (BHV-1) and bovine viral diarrhea virus (BVDV) in association with the in vitro production of bovine embryos. Theriogenology 40(3):531-538. <http://dx.doi.org/10.1016/0093691X(93)90406-U><PMid:16727336>

Campos F.S., Franco A.C., Hübner S.O., Oliveira M.T., Silva A.D., Esteves P.A., Roehe P.M. \& Rijsewijk F.A.M. 2009. High prevalence of co-infections with bovine herpesvirus 1 and 5 found in cattle in southern Brazil. Vet. Microbiol. 139(1/2):67-73. <http://dx.doi.org/10.1016/j.vetmic.2009.05.015> <PMid:19560292>

Can M.F., Ataseven V.S. \& Yalçin C. 2016. Estimation of production and reproductive performance losses in dairy cattle due to bovine herpesvirus 1 (BoHV1) infection. Vet. Arhiv 86:499-513.

Costa E.P. 1994. Aspectos morfológicos (citológicos e ultraestrututais) e desenvolvimento de ovócitos de bovinos in vitro. Tese de Doutorado, Universidade Federal de Minas Gerais, Belo Horizonte. 155p.

Costa E.P., Vale Filho V.R., Nogueira J.C., Costa A.H.A., Camargos E.R.S., Ferreira A.M. \& Bruschi J.H. 1997a. Técnicas para desnudamento rápido de ovócitos de bovinos. Arq. Bras. Med. Vet. Zootec. 49:425-432. 
Costa E.P., Vale Filho V.R., Nogueira J.C., Ferreira A.M. \& Costa A.H.A. 1997b. Técnica para a avaliação do estágio de maturação "in vitro" de ovócitos bovinos. Arq. Bras. Med. Vet. Zootec. 49:433-440.

D’Angelo M. 1998. Interação do Herpesvirus Bovino tipo-1 (BHV-1) com oócitos bovinos maturados in vitro. Tese de Doutorado, Universidade de São Paulo, São Paulo. 52p.

El-Mayet F.S., Sawant L., Thunuguntla P. \& Jones C. 2017. Combinatorial effects of the glucocorticoid receptor and Krüppel-like transcription factor 15 on bovine herpesvirus 1 transcription and productive infection. J. Virol. 91(21):e00904-e00917. <http://dx.doi.org/10.1128/JVI.00904-17> $<$ PMid:28794031>

Gilchrist G.C., Tscherner A., Nalpathamkalam T., Merico D. \& Lamarre J. 2016. MicroRNA expression during bovine oocyte maturation and fertilization. Int. J. Mol. Sci. 17(3):396. <http://dx.doi.org/10.3390/ijms17030396> <PMid:26999121>

Gonçalves R.F., Soares R.M., Orlandi C.M.B., Richtzenhain L.J., Visintin J.A. \& D’Angelo M. 2015. In vitro interaction of bovine herpesvirus 1 with uterine tube epithelial cells and oocytes. Arqs Inst. Biológico, São Paulo, 82:1-6.

IBGE 2017. Agência IBGE Notícias. Available at <https://agenciadenoticias. ibge.gov.br/2012-agencia-de-noticias/noticias/16994-rebanho-de-bovinostem-maior-expansao-da-serie-historica.html> Accessed on Nov. 5, 2017.

IETS 2015. Statistics of embryo collection and transfer in domestic farm animals. Available at <www.iets.org/pdf/comm_data/December2015. pdf $>$ Accessed on June 22, 2017.

Jones C., Newby T.J., Holt T., Doster A., Stone M., Ciacci-Zanella J., Webster C.J. \& Jackwood M.W. 2000. Analysis of latency in cattle after inoculation with a temperature sensitive mutant of bovine herpesvirus 1 (RLB106). Vaccine 18(27):3185-3195. <http://dx.doi.org/10.1016/S0264-410X(00)00106-7> <PMid:10856798>

Kramps J.A., Perrin B., Edwards S. \& Van Oirschot J.T. 1996. A European interlaboratory trial to evaluate the reliability of serological diagnosis of bovine herpesvirus 1 infections. Vet. Microbiol. 53(1/2):153-161. <http://dx.doi. org/10.1016/S0378-1135(96)01243-6><PMid:9011007>

Mahmoudi R., Subhani A., Pasbakhsh P., Abolhasani F., Amir I.I., Salehnia M. \& Etesam F. 2005. The Effects of cumulus cells on in vitro maturation of mouse germinal vesicle stage oocytes. Iran J. Reprod. Med. 3:74-78.

Makarevich A.V., Pivko J., Kubovicova E., Chrenek M., Slezakova M. \& Louda F. 2007. Development and viability of bovine preimplantation embryos after the in vitro infection with bovine herpesvirus-1 (BHV-1): immunocytochemical and ultrastructural studies. Zygote 15(4):307-315. <http://dx.doi.org/10.1017/S0967199407004303><PMid:17967210>

Miller J.M. \& Van der Maaten M.J. 1986. Experimentally induced infectious bovine rhinotracheitis virus infection during early pregnancy: effect on the bovine corpus luteum and conceptus. Am. J. Vet. Res. 47(2):223-228. $<$ PMid:2420240>

Moore S., Gunn M. \& Walls D. 2000. A rapid e sensitive PCR based diagnostic assay to detect bovine herpesvírus 1 in routine diagnostic submissions. Vet. Microbiol. 75(2):145-153. <http://dx.doi.org/10.1016/S03781135(00)00210-8> <PMid:10889405>

Mueller S.B.K., Ikuno A.A. \& Machado T.S. 1981. Prevalência de anticorpos contra o vírus da Rinotraqueíte Infecciosa Bovina / Vulvovaginite Pustular Infecciosa (IBR/IPV) em bovinos do Estado de São Paulo. Arqs Inst. Biológico, São Paulo, 47:55-59.

Muylkens B., Thiry J., Kirten P., Schynts F. \& Thiry E. 2007. Bovine herpesvirus 1 infection and infectious bovine rhinotracheitis. Vet. Res. 38(2):181-209. <http://dx.doi.org/10.1051/vetres:2006059><PMid:17257569>

Nandi S., Kumar M., Yadav V. \& Chander V. 2011. Serological evidences of bovine herpesvirus-1 infection in bovines of organized farms in India. Transbound. Emerg. Dis. 58(2):105-109. <http://dx.doi.org/10.1111/j.1865-1682.2010.01185. $\mathrm{x}><$ PMid:21156033>
OIE 2010. Terrestrial Animal Health Code. Office International Des Epizooties. Available at <http://www.oie.int/international-standard-setting/terrestrialmanual/access-online/> Accessed on Mar. 28, 2017.

Oliveira A.P. 2014. Herpesvírus Bovino em complexos cumulus-oócitos e fluido folicular em vacas sorologicamente positivas. Tese de Doutorado, Universidade Federal de Minas Gerais, Belo Horizonte. 48p.

Oliveira A.P., Heinemann M.B., Cortez A., Nascimento P.M.P., Leite R.C. \& Viana J.H.M. 2016. Bovine herpesvirus type 1 in cumulus-oocyte complexes collected from naturally infected cows. Pesq. Agropec. Bras. 51(5):676-679. <http://dx.doi.org/10.1590/S0100-204X2016000500031>

Olmos A., Esteban 0., Bertolini E. \& Cambra M. 2003. Nested RT-PCR in a single closed tube, p.151-159. In: Bartlett J.M.S. \& Stirling D. (Eds), Methods in Molecular Biology: PCR protocols. $2^{\mathrm{a}}$ ed. Humana Press, Totowa, New Jersey.

Patel J.R. 2005. Characteristics of live bovine herpesvirus-1 vaccines. Vet. J. 169(3):404-416. <http://dx.doi.org/10.1016/j.tvjl.2004.03.005> <PMid:15848783>

Pereira E.C.M., Costa E.P., Silva Júnior A., Mendes V.R.A., Santos G.M., Costa S.L. \& Santos M.R. 2015. Natural infection in ovarian structures by bovine herpesvirus 1: molecular and serological detection. Semina, Ciênc. Agrárias 36:863-869.

Perry G.H. 2005. Analyzing disease transmission risks from abattoir-derived in vitro-produced bovine embryos. Reprod. Fertil. Develop. 17(2):244-251. <http://dx.doi.org/10.1071/RDv17n2Ab187>

Piovesan M., Fernandes M.H.V., Corrêa R.A., Prado M.H.J., Camargo A.D. \& Rodrigues P.R.C. 2013. Anticorpos contra o herpesvírus bovino tipo 1, vírus da diarreia viral bovina e vírus da leucose enzoótica bovina na região da campanha do estado do Rio Grande do Sul. Sci. Anim. Health 1:38-49.

Puentes R., Campos F.S., Furtado A., Torres F.D., Franco A.C., Maisonnave J. \& Roehe P.M. 2016. Comparison between DNA detection in trigeminal nerve ganglia and serology to detect cattle infected with bovine herpesviruses types 1 and 5. Plos One 11(5):1-9. <http://dx.doi.org/10.1371/journal. pone.0155941 ><PMid:27224314>

Ravazzolo A.P., Pizzol M.D. \& Moojen V. 1989. Evidência da presença de anticorpos para o vírus da Rinotraqueíte Infecciosa dos Bovinos, em alguns municípios do Estado do Rio Grande do Sul, Brasil. Arq. Fac. Vet. UFRGS 17:89-95.

Ravishankar C., Nandi S., Chander V. \& Mohapatra T.K. 2013. Concurrent testing of breeding bulls for bovine herpesvirus 1 infection (BHV-1) in India. Vet. Ital. 49(2):145-150. <PMid:23888414>

Rocha M.A., Gouveia A.M.G. \& Leite R.C. 1999. Herpesvírus bovino tipo 1 no sêmen. Ciência Rural 29(2):373-380. <http://dx.doi.org/10.1590/ S0103-84781999000200032>

Rocha M.A., Gouveia A.M.G., Lobato Z.I.P. \& Leite R.C. 2001. Pesquisa de anticorpos para IBR em amostragem de demanda no Estado de Minas Gerais, 1990-1999. Arq. Bras. Med. Vet. Zootec. 53(6):645-647. <http:// dx.doi.org/10.1590/S0102-09352001000600003>

Rocha M.A., Barbosa E.F., Guimarães S.E.F., Dias Neto E. \& Gouveia A.M.G. 1998. A high sensitivity-Nested PCR assay for BoHV-1 detection in semen of naturally infected bulls. Vet. Microbiol. 63(1):1-11. <http://dx.doi. org/10.1016/S0378-1135(98)00213-2> <PMid:9810617>

Sampaio I.B.M. 2002. Estatística Aplicada à Experimentação Animal. 2ª ed. Fundação de Ensino e Pesquisa em Medicina Veterinária e Zootecnia Belo Horizonte. 265p.

Santos M.R., Ferreira H.C.C., Carvalho O.V., Soares J.A., Campos V.E.B., Costa E.P., Almeida M.R. \& Silva Júnior A. 2014. Surveillance of neutralizing antibodies against bovine herpesvirus 1 in cattle herds from different farming property systems. Biosci. J. 30:803-809.

Spear P.G. 2004. Herpes simplex virus: receptors and ligands for cell entry. Cell Microbiol. 6(5):401-410.<http://dx.doi.org/10.1111/j.1462-5822.2004.00389. $\mathrm{x}><$ PMid:15056211>

Takiuchi E., Médici K.C., Alfieri A.F. \& Alfieri A.A. 2005. Bovine herpesvirus type 1 abortions detected by a semi Nested-PCR in Brazilian cattle herds 
Res. Vet. Sci. 79(1):85-88. <http://dx.doi.org/10.1016/j.rvsc.2004.11.005> <PMid:15894030>

Thibier M. \& Wrathall T. 2012. International trade of livestock germplasm, 4p. In: Heldman D.R., Wheeler M.B. \& Hoover D.G. (Eds), Encyclopedia of Biotechnology in Agriculture and Food. Vol.25. 5a ed. CRC Press, New York.

Tsuboi T. \& Imada T. 1997. Effect of bovine herpes virus- 1, bluetongue virus and akabane virus on the in vitro development of bovine embryos. Vet. Microbiol. 57(2/3):135-142. <http://dx.doi.org/10.1016/S03781135(97)00138-7><PMid:9355248>

Tsuboi T., Kanazawa Y., Syoji T. \& Tokuhisa S. 1992. Growth activity of bovid herpesvírus 1 in bovine follicular oocytes with cumulus cells. J. Vet. Med. Sci. 54(6):1179-1181. <http://dx.doi.org/10.1292/jvms.54.1179> <PMid:1477167>

Vanroose G., Nauwynck H., Van Soom A., Vanopdenbosch E. \& De Kruif A. 1999. Effect of bovine herpesvirus-1 or bovine viral diarrhea virus on development of in vitro-produced bovine embryos. Mol. Reprod. Develop. 54(3):255-263.

Vidor T., Halfen D.C., Leite T.E. \& Coswig L.T. 1995. Herpesvírus bovino tipo 1(HVB-1), sorologia de rebanhos com problemas reprodutivos. Ciência Rural 25(3):421-424. <http://dx.doi.org/10.1590/S0103-84781995000300016>

Weber M.N., Galuppo A.G., Budaszewski R.F., Corbellini A.O., Mósena A.C.S., Pinto L.D., Marques L.S., Rodrigues J.L. \& Canal C.W. 2013. Evaluation of prenucleic acid extraction for increasing sensitivity of detection of virus in bovine follicular fluid pools. Theriogenology 79(6):980-985. <http:// dx.doi.org/10.1016/j.theriogenology.2013.01.022> <PMid:23427937>.

Winkler M.T., Doster A. \& Jones C. 2000. Persistence and reactivation of bovine herpesvirus 1 in the tonsils of latently infected calves. J. Virol. 74(11):5337-5346. <http://dx.doi.org/10.1128/JVI.74.11.5337-5346.2000> <PMid:10799611> 